\title{
STARE DRUKI BIBLIOTEK GIMNAZJALNYCH CHOJNIC I CHEŁMNA W ZBIORACH BIBLIOTEKI UNIWERSYTETU MIKOŁAJA KOPERNIKA
}

Zbiory bibliotek gimnazjalnych z Chojnic i Chełmna wpłynęły do Biblioteki UMK w pierwszym okresie organizowania się nowej uczelni, tj. w roku $1946^{1}$. Informacje - tych księgozbiorach przekazał władzom Uniwersytetu ówczesny adiunkt dr Leonid Żytkowicz. On też potem, po uzyskaniu przez Uniwersytet zezwolenia Kuratorium Okręgu Szkolnego na przejęcie tych zbiorów, przewoził je do Torunia ${ }^{2}$. Książki były składowane w tzw. „zbiornicy”, następnie w kolejnych latach segregowane i sukcesywnie opracowywane.

Mówiąc o bibliotekach gimnazjalnych mamy na uwadze Państwowe Gimnazjum Męskie działające w Chojnicach w okresie 1815-1939 oraz Państwowe Gimnazjum Męskie działające w Chełmnie w latach 1837-1939. Nie obejmujemy tu zbiorów po tzw. „Akademii Chełmińskiej” (umowna nazwa stosowana w literaturze dla szkoły średniej w Chełmnie funkcjonującej w zmieniającej się formie i warunkach w okresie 1386-1818). Księgozbiór tejże Akademii przejęła w 1817 roku Męska Szkoła Wydziałowa połączona z Męską Szkołą Ewangelicką - późniejsze progimnazjum, a następnie tzw. Wyższa Szkoła Miejska i Obywatelska (Höhere Stadt und Bürger Schule). W okresie II Rzeczypospolitej w miejsce tejże szkoły powstało Państwowe Gimnazjum Żeńskie, które w naturalny sposób odziedziczyło majątek po poprzednikach, w tym także księgozbiór po Akademii ${ }^{3}$. To długie wyjaśnienie wydaje się być konieczne, ponieważ obiegowo łączy się Akademię Chełmińską (1386-1818) z późniejszym Gimnazjum Męskim (1837-1939), co jest jednak niezgodne $z$ faktami.

Oba gimnazja są ze sobą porównywalne. Powstały w tym samym okresie i funkcjonowały w tych samych warunkach. Były to państwowe gimnazja męskie, katolickie (Königliche katholische Gymnasium zu Conitz; zu Culm). Podlegaty tym samym władzom szkolnym, obowiązywały je te same zarządzenia i organizacja. W obu kształciła się obok niemieckiej młodzież polska. Oba gimnazja zasłużyły się dla kultury polskiej, przygotowując polską inteligencję. W związku z powyższym doczekały się już wielu opracowań ${ }^{4}$. Nas interesuje przede wszystkim biblioteka, a ściślej część zabytkowego księgozbioru bibliotek nauczycielskich obu szkól. Należy jednak wspomnieć, że w gimnazjach tych obok biblioteki nauczycielskiej były biblioteki uczniowskie dla poszczególnych klas, w pewnym okresie - od Wiosny Ludów do Kulturkampfu - biblioteki polskie, tajne filomackie oraz przy konwiktach. Jest to jednak odrębne zagadnienie badawcze. 
Prześledzenie zasobu starych druków w bibliotekach gimnazjalnych stanowi ważny, jak to będziemy starali się udowodnić, przyczynek do historii bibliotek pomorskich. Szczęśliwie zachowały się źródła rękopiśmienne i drukowane odnoszące się do obu księgozbiorów. W Bibliotece UMK przechowywany jest katalog biblioteki gimnazjalnej w Chojnicach ${ }^{5}$. Stare druki nie są $w$ nim wyodrębnione, lecz opisane w poszczególnych działach z różnym stopniem szczegółowości. W Wojewódzkim Archiwum Państwowym w Bydgoszczy w Aktach Okręgu Szkolnego Pomorskiego znajduje się spis ponad 330 starych druków przechowywanych w gimnazjum chojnickim przed II wojną światowa ${ }^{6}$. Bardzo istotne $z$ punktu widzenia omawianego zagadnienia jest zestawienie dyrektora gimnazjum $\mathrm{H}$. Deitersa w programie z roku $1874 / 75^{7}$. Warto też wspomnieć o szkicu poświęconym bibliotece gimnazjum chojnickiego pióra Stanisława Tynca ${ }^{8}$. Zachował się również rękopiśmienny katalog biblioteki nauczycielskiej w Chelmnie ${ }^{9}$. Katalog ten został opublikowany w 1901 roku $^{10}$. Podobnie jak w Chojnicach, w drukowanym programie szkolnym z roku 1876 opisano 73 druki z XV i XVI wieku ${ }^{11}$. Spisy te wykonano na polecenie Prowincjonalnego Kolegium Szkolnego w Królewcu. W Chełmnie spis opracowano z opóźnieniem. Ministerstwo monitowało dyrektora gimnazjum - Wojciecha Łożyńskiego o wydrukowanie spisu cennych rękopisów i druków z XV i XVI wieku, o czym świadczy zachowana korespondencja ${ }^{12}$. W instrukcji Prowincjonalnego Kolegium Szkolnego wskazano na konieczność zaznaczenia na karcie tytułowej programu informacji o zamieszczonym spisie. Byla to więc zaplanowana i konsekwentna akcja władz pruskich rejestracji cennych zabytków piśmiennictwa znajdujących się w bibliotekach szkolnych. Dziś spisy te mają dużą wartość historyczną, zwłaszcza tam, gdzie opisy są dokładne z zaznaczeniem stanu zachowania, proweniencji itp. Wiele bowiem księgozbiorów już nie istnieje albo są w formie szczątkowej. Spis gimnazjum chojnickiego jest w stosunku do chełmińskiego bogatszy o takie właśnie informacje. Spis chelmiński jest schematyczny, ujęty tabelarycznie.

Obie biblioteki miały ten sam start. Organizowały się od początku. Gimnazjum chojnickie, które mieściło się w budynku po dawnym kolegium jezuickim, nie odziedziczyło po nim praktycznie żadnych ksiażek poza pojedynczymi egzemplarzami. Obie szkoły organizowały się z trudem, borykając się z wieloma problemami przy bardzo ograniczonych środkach finansowych. Na książki pieniędzy oczywiście nie było, więc władze przeznaczały do tych szkół część książek z bibliotek klasztornych Pomorza kasowanych $w$ tym czasie przez administrację pruską ${ }^{13}$. Z punktu widzenia funkcjonowania szkoły nie wszystkie książki zwożone z klasztorów były w niej przydatne i wykorzystywane w codziennej pracy. Na początku nie bylo żadnych, więc korzystano z tego, co wpłynęto z klasztorów. Z czasem większość $z$ nich miała jedynie charakter zabytkowy i historyczny, sporadycznie zapewne były wykorzystywane przez nauczycieli lub pojedyncze osoby z miejscowego środowiska. Zasługa tych bibliotek $-z$ dzisiejszego punktu widzenia - był sam fakt opracowania i przechowywania książek i tylko ten aspekt jest rozpatrywany w niniejszych rozważaniach. Dzisiaj księgozbiory te, ze względu na swój instytucjonalny charakter opracowania - charakterystyczne nalepki z sygnaturami - dają się 
zewnętrznie wyodrębnić w magazynie ksiażek, co umożliwiło podjęcie ich poszukiwań i badań nad nimi.

Gimnazjum w Chojnicach, które powstało o 22 lata wcześniej, otrzymało książki po skasowanych klasztorach bernardynów w Lubawie, reformatów z Wejherowa, jezuitów z Grudziądza, dominikanów z Torunia oraz benedyktynek z Żarnowca. Przejęto też to, co zostało po miejscowych klasztorach jezuitów i augustianów, ale było tam, jak już nadmieniono, niewiele książek. Trudno dziś bardzo dokładnie określić wielkość zbioru starych druków gimnazjum w Chojnicach. Zestawienie z roku 1874 wykazuje 8 rękopisów w 12 woluminach, 35 inkunabułów w 24 woluminach, 100 druków XVI wieku w 80 woluminach. Brakuje danych z wieku XVII i XVIII. Aktualnie w zbiorach Biblioteki UMK zarejestrowano 3 rękopisy, 6 (7?) inkunabułów ${ }^{14}, 95$ druków z wieku XVI, $47-z$ XVII oraz $153-z$ XVIII. Razem ponad 300. Spis z roku 1931 znajdujący się w Wojewódzkim Archiwum Państwowym w Bydgoszczy liczy 337 pozycji, w tym 2 inkunabuly (!) i około 60 druków z XVIII wieku. W zestawieniu z wyżej wymienionymi danymi o aktualnie zarejestrowanych drukach z tejże biblioteki widać, jak dane z roku 1931 są nieścisłe. Nie mogły przecież przed II wojną światową znajdować się tylko dwa inkunabuły w jednym woluminie skoro dziś jest na pewno 6. Całkowicie ścisłych danych nie da się więc ustalić, zawsze będą tylko dane przybliżone.

Te same dane dla gimnazjum w Chełmnie przedstawiają się następująco: w zestawieniu z roku $1876^{15}$ opisany został tylko jeden rękopis pergaminowy (dzieło Grzegorza Wielkiego), 4 inkunabuły, 69 dzieł z XVI wieku w 74 tomach oraz wspomniano o istnieniu 145 druków w 156 woluminach z XVII wieku. Aktualnie w kartotekach proweniencyjnych wynotowanych mamy 12 druków z XVI wieku, 112 - zXVII oraz 154 - zXVIII. W Wojewódzkim Archiwum Państwowym w Bydgoszczy nie ma analogicznego spisu sporządzonego na polecenie Kuratorium w roku 1931. Dyrektor gimnazjum - dr Czesław Frankiewicz - przesłał drukowany katalog z 1901 roku z podkreślonymi czerwoną kredką pozycjami druków z XV-XVIII wieku. W załączonym piśmie zaznaczył, że mogą być pewne braki, gdyż biblioteka jest zdekompletowana i dopiero w połowie uporządkowana ${ }^{16}$. Wzmiankowany katalog nie numeruje pozycji, ale z obliczeń własnych autorki mynika, że zawiera 4765 pozycji, w tym 486 starych druków. Wielkość więc obu zbiorów była zbliżona, choć ilościowo więcej starych druków posiadało gimnazjum w Chełmnie. W wyniku akcji Kuratorium z roku 1931 pewną część książek z biblioteki gimnazjalnej w Chełmnie przekazano do biblioteki Uniwersytetu w Poznaniu. Ekslibris z notką: „BUP, Dar Kuratorium Okr. Sz. Poznańskiego. Z Biblioteki Gimn. Męsk. w Chełmnie" ma datę 1936 r. Wskazuje na to powielany katalog poloników XVI wieku Biblioteki Głównej Uniwersytetu im. Adama Mickiewicza w Poznaniu, gdzie 7 pozycji ma interesującą nas proweniencję ${ }^{17}$. Wśród książek, które trafiły wtedy do Poznania, jest Biblia zwana Radziwiłlowską, wydana w Brześciu w 1563 roku oraz dzieła prawnicze Mikołaja Jaskera z proweniencją księży misjonarzy z Chełmna. Przypuszczać można, że wśród druków Biblioteki UAM w Poznaniu, zwlaszcza obcych XVI wieku, będzie można z czasem znaleźć książki z biblioteki gimnazjalnej w Chełmnie ${ }^{18}$. Znajdowało się $w$ niej bowiem ponad 70 druków z tej epoki, a obecnie mamy w kartotekach proweniencji Biblioteki UMK zarejestrowanych tylko 12 druków z XVI 
stulecia i to często zdefektowanych. Druki XVI-wieczne, bardzo atrakcyjne pod względem typograficznym i treściowym, były zapewne obiektem zainteresowania Biblioteki Uniwersyteckiej w Poznaniu.

Książki z gimnazjum w Chojnicach pozostały na miejscu, choć Stanisław Tync w swoim szkicu sugerował, aby przekazać je Książnicy Miejskiej w Toruniu, gdzie naukowo opracowane służyłyby zainteresowanym badaczom ${ }^{19}$.

W obu bibliotekach interesujące nas partie księgozbiorów, zwlaszcza druki XVI i XVII stulecia, były przede wszystkim pochodzenia klasztornego lub kościelnego, gdyż jak wiadomo biblioteki te otrzymały część książek ze skasowanych klasztorów Pomorza. Pojedyncze ksiażki, które do obu bibliotek wpływały od indywidualnych ofiarodawców, też noszą ślady dawnej przynależności do zbiorów kościelnych i klasztornych. $Z$ opuszczonych, niezabezpieczonych, a więc często bezpowrotnie zniszczonych księgozbiorów w okresie kasaty, okoliczna ludność czasami przechowała pewną ilość ksiażek, a potem przekazywała je do bibliotek gimnazjalnych. Zaś sam fakt przekazywania ksiażek przez poszczególnych obywateli, których synowie kształcili się w gimnazjach lub przez absolwentów, a także nauczycieli i księgarzy świadczy o tym, że społeczności lokalne wiedziały o tych bibliotekach i uważały, że jest to stosowne miejsce na przechowanie zabytkowych książek, nieprzydatnych $w$ domowych księgozbiorach ${ }^{20}$. Jest też dowodem wielkiej dezorganizacji kasowanych zbiorów. Wielkie destrukcje zasobów książkowych miały miejsce i później. W okresie I wojny światowej nastappiły kolejne uszczuplenia zbiorów. Nauczanie odbywało się przecież w warunkach wojennych. Opuszczający potem te tereny Niemcy zabierali ze sobą również dobra materialne i kulturalne, albo ginęły one $z$ braku dozoru. W tym czasie na przykład zginęla w Chojnicach edycja dzieł Arystotelesa w języku greckim, wydana w latach 1495-1498 przez Alda Manutiusa $w$ jego weneckiej oficynie, wydrukowana zresztą na pergaminie i pochodząca $z$ klasztoru bernardynów w Lubawie ${ }^{21}$.

Na początku II Rzeczypospolitej szkoły na Pomorzu od nowa musiały budować swoje zbiory polskie. Nie było warunków dla szczególnego zajmowania się starymi drukami. Niemniej, podjęto pewne prace dokumentacyjne, czego wynikiem było wydawnictwo "Biblioteki wielkopolskie i pomorskie" opracowane pod redakcja Stefana Wierczyńskiego. II wojna światowa stała się kolejną katastrofą. Zdewastowane i uszczuplone zbiory, po II wojnie zostały z Chełmna i Chojnic przewiezione do Biblioteki UMK. Część z nich znalazła się w rękach prywatnych właścicieli (na przykład u p. Albina Makowskiego w Chojnicach w jego "Kolekcji Historyczno-Regionalnej" - obecnie w Muzeum Historyczno-Etnograficznym w Chojnicach). Pojedyncze egzemplarze pojawialy się i pojawiają w handlu antykwarycznym. W Bibliotece UMK zbiory te również uległy rozbiciu. Chronologicznie wyodrębnione stare druki były sukcesywnie opracowywane. Nadawano im odpowiednie sygnatury według podziału na druki obce i polonika, wieki i formaty. Tak wiec nie stoja jako samodzielna kolekcja, lecz są rozproszone po całym magazynie ${ }^{22}$. Niemniej dają się wyodrębnić na podstawie nalepek na grzbietach oraz pieczątek wewnątrz $\mathrm{i}$ innych rozpoznawalnych znakach, jak sygnatury na wewnętrzenej stronie okładek, pisane tą samą ręką i w ten sam sposób. 
Książki z biblioteki gimnazjum w Chojnicach maja na grzbietach kolorowe nalepki: żółte, niebieskie, zielone wraz z sygnaturą. Na wewnętrznej stronie okładki mają często po trzy sygnatury (dwie z nich później przekreślono jako nieaktualne). Pierwszą z nich był kolejny numer inwentarza, następną duża litera alfabetu oznaczająca dział oraz liczba, a trzecią duża litera (czasami inna niż poprzednio, gdy zmieniono oznaczenie działu, $\mathrm{np} . \mathrm{N}=$ teologia, potem I = teologia) oraz dwie cyfry po przecinkach. Czasami spotyka się cyfry rzymskie oznaczające duży format, co znaczy, że "folia" były wydzielone. Są to ślady kolejnych melioracji i porządkowania zbiorów ${ }^{23}$. Oprócz nalepek i sygnatur na wewnętrznej stronie okładki lub karcie tytułowej była odbijana czama pieczęć okrągła z napisem w otoku: „Des Köngl[iches] Gymn[asiums] Bibliothek" a w środku „zu Conitz”.

Książki z gimnazjum w Chełmnie mają na grzbiecie białe nalepki (czasami z niebieską obwódka) wraz z sygnaturą składającą się z cyfry rzymskiej i arabskiej. Te nalepki i sygnatura pochodzą z okresu II Rzeczypospolitej ${ }^{24}$. Wewnątrz książki, przeważnie na karcie tytułowej lub jej odwrociu, znajduje się okrągła pieczęć, najczęściej odbijana czerwonym tuszem, z napisem w środku: „Ex Bibliotheca Gymnasii Culmensis".

Wśród książek z gimnazjum chojnickiego odnaleziono ksiażki z dawnego klasztoru bernardynów w Lubavie ${ }^{25}$ w ilości 90 pozycji bibliograficznych, $w$ tym trzy rękopisy, a wśród nich „Modlitewnik” biskupa Wincentego Kiełbasy (ok. 1425-1486) oraz 4 inkunabuły. Jednak przeważnie są to druki $z X V I$ wieku o charakterze renesansowym, pochodzące ze znanych oficyn drukarskich Włoch, Szwajcarii, Holandii, Niemiec i Francji. Znajdujemy tu dzieła słynnych autorów epoki, takich jak Piotr Ramus, Aldus i Pawet Manucjusze, Henryk i Robert Estienne'owie, Erazm z Rotterdamu, Filip Melanchton, Juliusz Cezar Scaliger oraz dzieła pisany starożytnych: Ajschylosa, Eurypidesa, Arystotelesa, Cicerona. Książki mają nierzadko bardzo ciekawe, dobrze zachowane oprawy. Wszystko to stało się inspiracją do napisania odrębnego artykułu opublikowanego w $1986 \mathrm{roku}^{26}$, gdyż trudno było nie zająć się biblioteka, z której pochodzi „pelpliński” egzemplarz Biblii Gutenberga.

Natrafiono również na książki z biblioteki reformatów z Wejherowa ${ }^{27}$, w ilości 20 egzemplarzy. Na ogół na książkach tej proweniencji znajduje się nota: „pro loco Weiheropoliensi Fratrum Minorum Reformatorum Provinciae S. Antonii de Padua" lub w trochę odmiennej formie. Można te książki rozpoznać po charakterystycznej sygnaturze biblioteki wejherowskiej, pisanej dużymi „drukowanymi” literami na nalepce grzbietowej i wyklejce górnej okładziny. Są to, poza pięcioma drukami z XVI wieku, głównie książki XVII-wieczne, a wśród nich "Lyricon libri IV" M.K. Sarbiewskiego, wydany w Antwerpii w 1632 roku u Plantina (BUT, sygn. Pol.7.II.748) oraz trzy prace znanego włoskiego przyrodnika U. Aldrovandiego (Ob.7.III.1146: Ob.7.IV.77; Ob.7.IV.78).

Kolejną większą grupa proweniencyjną z biblioteki chojnickiej są książki po augustianach chojnickich ${ }^{28}$. Znaleziono ich 8 (Ob.6.IV.265; Ob.6.II.4305; Ob.6.II.2562; Pol.7.IV.32; Pol.7.I.14-18; Pol.8.I.27; Pol.8.II.282; 265331).

Wiadomo z literatury przedmiotu, że biblioteka gimnazjalna w Chojnicach otrzymała część ksiażek po dominikanach toruńskich. Aktualnie wynotowano 4 pozycje $z$ tej biblioteki, ale proweniencja nie jest całkowicie pewna. Zapiski i 
oznakowania są mało czytelne, podobne do wielu innych i można tu popełnić błędy. Wą̧tpliwości nie budzi inkunabuł z sygnaturą Inc,III.52, z notą na pierwszej karcie: „Con[ventus] Torunensis . [Dominicanorum] est iste liber" oraz "Pro noviciatu "Con[ven]tus Thorunen[sis] Ord[in]is Praed[icatoru]m"29 , a także „Grammatica Latina" J. Rheniusa wydana w Lipsku w 1677 roku (sygn. Ob.7.II.3423), gdzie na karcie ochronnej górnej okładziny jest notka: „pro Bibliotheca noviciatus conventus Thorunensis".

$Z$ innych zbiorów poklasztornych wynotowano dwie ksiażki bernardynów z Zamartego (Jakobsdorf) koło .Chojnic ${ }^{30}$ (Ob.6.III.12 i Pol.7.III.280). Obie zostały konwentowi podarowane w 1761 roku przez bliżej nieznanego p. Jezierskiego. Szczególnie interesującą notę ma druk oznaczony sygnaturą Pol.7.III.280 : A.M. Fredro, Gestorum Populi Poloni sub Henrico Valesio. Dantisci, G. Förster, 1652. $4^{\circ}$. Jest to bowiem egzemplarz autorski Fredry z jego własnoręczną adnotacją: „Hoc opus post primam impressionem ab ipsomet auctore recognitum et correctum multi enim errores irrepserant ad secunda[m] impressione $[\mathrm{m}]$ emmendandi anno Dei Nati 1656 die 20 Mai Andrzej Maximilian Fredro castellanus Leopoliensis m[anu] p[ro]p[ria]" (k.4.v.). Szkoda, że nie zachowała się karta tytułowa i ochronna, na których mogły znajdować się jeszcze inne adnotacje, być może wydawcy - Georga Förstera, który niewątpliwie miał ten egzemplarz w ręce, gdyż był on podstawą dwóch następnych wydań już poprawionych ${ }^{31}$. Ta informacja może zainteresować polskich historiografów.

Chociaż z zachowanych źródeł wynika, iż w zespole chojnickim powinny znajdować się pojedyncze egzemplarze po miejscowych jezuitach, to jednak nie natrafiono na nie. Znaleziono też w zespole chojnickim tylko jedną książkę należącą do jezuitów w Grudziądzu, ale za to z bardzo interesującymi wcześniejszymi proweniencjami. Jest to dzieło N. Perotti'ego "Cornucopiae, sive Linguae Latinae Commentarii", wydane w Wenecji, w drukarni Manucjuszów, w 1513 roku, $2^{\circ}$. (Ob.6.III.531). Pierwszym właścicielem był Fryderyk Fischer (1485-1529), który nabył je w Bolonii w 1516 roku. Kolejnym właścicielem był Paweł Speratus (14841554), teolog i kaznodzieja luterański zwiazany z Uniwersytetem w Królewcu. Na wewnętrznej stronie okładki znajduje się jego ekslibris. Speratus był znanym bibliofilem, a jego znak własnościowy byl już przedmiotem opublikowanej analizy ${ }^{32}$. Następnie ksiażka ta w nieznany nam sposób stała się własnością w XVII w. (1674) Jana Wawrzyńca Zadrożeńskiego. Kolejnymi jej właścicielami stali się jezuici w Grudziądzu, o czym świadczy notka: „collegii Graudentini[ensis] Societatis Jesu”.

Większą ilość książek przekazał bibliotece gimnazjainej w Chojnicach N.G. Benwitz - radca i kupiec chojnicki. Wśród książek przez niego ofiarowanych były wartościowe rękopisy po burmistrzu i historyku chojnickim Izaaku Godfrydzie Goedtke (1691-1765), które do naszych czasów nie zachowały się. Obecnie mamy wynotowanych 12 pozycji z monogramem pieczętnym Benwitza i jego podpisem. Obok podpisu znajdują się daty 1824-1826. Przypuszczalnie są to daty kupna. Książki przez Benwitza podarowane przedstawiają dużą wartość. Jest między nimi inkunabuł "Legenda aurea" Jakuba de Voragine (Basel, Nicolaus Kessler, 25.VI.1480. $\left.2^{\circ}\right)^{33}$, Ch. Hartknocha „Preussische Kirchen-Historia" wydana we 
Frankfurcie nad Menem i Lipsku w 1688 roku (Pol.7.II.341) oraz inne dzieła o treści historyczno-geograficznej.

Wynotowano również książki z podpisami nauczycieli chojnickich, przede wszystkim Inocentego Junkera - 13 pozycji, głównie o treści historycznej, m.in. „Histoire générale de Pologne" P.J. Solignac'a wydaną w Paryżu w 1750 roku (Pol.8.Il.26) oraz L. Baczki „Geschichte Preussen”, Königsberg 1800 (dublet do sygn. 86332; 93600).

Nie sposób wymienić wszystkich dawnych właścicieli książek, których w zespole chojnickim wynotowano około 150 . Wielu z nich pozostanie anonimowymi, gdyż jedynym ich śladem jest mało czytelny, zatarty podpis lub same tylko inicjały.

W grupie ksiażek gimnazjum chełmińskiego wynotowano ponad 100 właścicieli indywidualnych oraz instytucji. W zespole tym najliczniejszą grupą proweniencyjną są książki jezuitów z Grudziądza ${ }^{34}$ - ponad 50 pozycji. Znajdują się tu ksiażzi będące ozdobą każdej kolekcji starych druków, jak na przykład A. Vesaliusa: „De humani corporis fabrica libri septem" - dzieło wydane u Oporina w Bazylei w 1555 roku (Ob.6.IV.117). Są też inne książki z zakresu medycyny, takie jak J. Fernela "Universa medicina", Frankfurt a/M 1578 (Ob.6.III.596). Obie wyżej wymienione książki należały wcześniej do Jana Webera konsula i sekretarza chełmińskiego, jak głosi notka na tych drukach. Wspomnieć warto trzecią książkę z tej dziedziny, już z XVII wieku, a mianowicie pracę L. Rivièr'a „Opera medica universa", opublikowaną w Lejdzie w 1679 roku (Ob.7.IV.48). Poza tym wśród książek $z$ dawnej biblioteki jezuitów z Grudziądza są książki z innych dziedzin wiedzy: matematyki, historii, geografii, wymowy, filozofii i literatury oraz oczywiście dotyczące bezpośrednio zakonu, a więc konstytucje i reguła zakonu jezuitów (Ob.7.II.2421-23), a także "Index generalis in omnes libros instituti Societatis Jesu", wydany w Antwerpii w 1635 roku (Ob.7.II.2455). Ponadto słowniki wielo- i dwujęzyczne (Calepinus, Knapski) oraz podręczniki wydawane przez ten zakon dla potrzeb własnego szkolnictwa, na przykład K. Wieruszewskiego „Laurea poetica...", Kalisz 1726 oraz Gabriela Rzączyńskiego „Armamentarium Regni Poloniae”, Poznań 1715 (Pol.8.II.73-74).

W obrębie zakonu jezuitów książki przechodziły z jednego domu zakonnego do innego. I tak w zespole książek jezuitów z Grudziądza natrafiono na trzy ksiażki z rezydencji chojnickiej. Widnieje na nich zapiska: „Residentiae Conecensis Soc[ietatis] Jesu post Collegii Graudentinensis S.J." (Ob.7.II.1565; Ob.7.I.349; Ob.7.II.7311). Znaleziono też jedną książkę należącą wcześniej do biblioteki jezuitów w Toruniu, z zapiską: „Inscriptus cathalogo librorum Collegii Torunensis Soc[ietatis] Jesu" (Ob.7.I.186).

W zespole książek gimnazjum chełmińskiego wynotowano 7 dzieł z proweniencją księży misjonarzy, którzy przebywali w Chełmnie w latach 1676-1818 i zajmowali się nauczaniem w Akademii Chełmińskiej oraz prowadzili diecezjalne seminarium duchowne. Książki swoje sygnowali notką: "Congr[egationis] Missinis domus Culmensis" ${ }^{35}$. Znaleziono też dwie książi z miejscowego konwentu franciszkanów (Pol.7.III.21; Ob.7.II.2451).

Spośród właścicieli indywidualnych najwięcej książek (13) wynotowano z podpisem: „F.L. Muszalla”, o którym na razie nic bliższego nie wiadomo. Z zapisek 
proweniencyjnych na jego książkach wynika jednak, że przejął on książki po Franciszku Hoffmannie - kapitanie Pomorskiej Gwardii Narodowej z roku $1807^{36}$. Pośród książek Franciszka Hoffmanna i F.L. Muszalli są dwie książki Gustawa Hoffmanna (Ob.7.Il.1398; Pol.8.Il.366), który był pisarzem miejskim, znanym z dokumentów historycznych, jako że znajdował się wśród obywateli miasta Chełmna zmuszonych do złożenia hołdu królowi pruskiemu Fryderykowi II w Malborku w 1772 r. $^{37}$ Ów Gustaw Hoffmann był zapewne przodkiem Franciszka. Natomiast Franciszek Hoffmann musiał być właścicielem większego, uporządkowanego księgozbioru, gdyż na jego książkach są informacje o miejscu przechowywania (szafa, półka i kolejny numer książki).

W zespole książek gimnazjum chełmińskiego na uwagę zasługje 5 dzieł, w 15-tu dużych woluminach, z ekslibrisem biskupa chełmińskiego Anastazego Sedlaga (1787-1856), znanego z wydania wrogiego rozporządzenia w roku 1838, skierowanego przeciwko Polakom, a dotyczącego wygłaszania kazań w języku niemieckim $^{38}$. Ekslibris biskupa o wymiarach $150 \times 95 \mathrm{~mm}$ ma kompozycję architektoniczną w postaci portalu gotyckiego. Wszystkie dzieła z jego ekslibrisem są treści religijnej, a szczególną uwagę zwraca 9 wielkich woluminów „Opera omnia” świętego Tomasza z Akwinu, wydanych w Antwerpii w 1612 roku, ze względu na kunsztowną, choć zmienianą później oprawę ze złoconym i cyzelowanym obcięciem kart oraz ze względu na superekslibris opata cystersów w Lubiążu - Dominika I. Superekslibris jest datowany na rok 1692, a na karcie tytułowej wszystkich tomów jest notka: „procuravit Reverendissimus Dominus D. Dominicanus I Lubensis Abbas anno 1692 B[eatae] M[ariae] V[irginis] in Lubens[is] Sac[ro] Ord[ine] Cister[ciensi]". Biskup Sedlag pochodził ze Śląska Opolskiego, a fakt posiadania przez niego książek tej proweniencji jest wynikiem pruskiej sekularyzacji zakonów na Śląsku, powodującej to zadziwiające rozproszenie, w tak nieoczekiwane miejsca, dawnych, wielowiekowych księgozbiorów.

W grupie książek gimnazjum chełmińskiego odnaleziono też trzy ksiązki pochodzące z Koronowa - miejscowości na Pomorzu, gdzie również przebywali cystersi. Ich właścicielem był Jan Robert Cichorski, który na książkach podpisał się w następujący sposób: „Ex libris Jacobi Robertis Cichorski prepositi Coronoviensis post Wierz[chucinensis]". Wszystkie trzy dzieła (sygn. 280042; 280044; 280045) to prace jednego autora, Hieronima Ferrari, z zakresu filozofii i matematyki, oprawione w szarą tekturę.

Warto na zakończenie omawiania proweniencji książek gimnazjum chełmińskiego wspomnieć, że spotyka się pojedyncze książki z nazwiskami rodzin znanych i zasłużonych na Pomorzu, takich jak Doniemirski (Ob.7.II.3082-3083; 275650; 278933), Działyński (Pol.7.IV.39), Działowski (Ob.7.I.276-277) oraz ks. Tułodziecki (Ob.7.II.2873-2874; Pol.8.III.2255;86364).

Przedstawiona wyżej charakterystyka starych druków bibliotek gimnazjalnych Chojnic i Cheimna z akcentem na ich wcześniejsze proweniencje potwierdza początkowe stwierdzenie, że zbiory te są konglomeratem wielu dawnych księgozbiorów historycznych Pomorza i ich pojedynczych reliktów. Kolekcje starych druków obu szkół powstały w wyniku przejmowania części dawnych księgozbiorów oraz z darów, co było przecież znane z literatury przedmiotu, ale nie znaliśmy stanu 
faktycznego na dzień obecny, a dla środowiska związanego z książką ich aktualne miejsce przechowywania nie było znane. Jeżeli przyjmiemy liczbę 337 starych druków znajdujących się w bibliotece gimnazjalnej w Chojnicach w roku 1931 za $100 \%$ (choć wiemy, że jest to liczba nieścisła) ${ }^{39}$ i zestawimy ją z 300 obecnie zarejestrowanymi w kartotece proweniencji Biblioteki UMK, to okazuje się, że w Bibliotece Uniwersytetu Mikołaja Kopernika znajduje się ok. 90\% ich stanu sprzed II wojny światowej. Dla biblioteki gimnazjalnej w Chełmnie dysponujemy danymi z innego okresu. W wyniku obliczeń opartych o drukowany katalog z 1901 roku wiemy, że starych druków było w tej bibliotece około 490 , a obecnie wynotowanych mamy 280 pozycji $^{40}$, czyli ok. $60 \%$ stanu sprzed I wojny światowej znajduje się dzisiaj w Bibliotece UMK ${ }^{41}$.

W stosunku do kilkutysięcznych zbiorów starych druków z biblioteki królewieckiej i elbląskiej, znajdujących się obecnie w Bibliotece UMK w Toruniu, obie zaprezentowane kolekcje są niewielkie. Niemniej dzięki nim zbiory Biblioteki UMK wzbogaciły się o wiele cennych druków pod względem treściowym, typograficznym, artystycznym i proweniencyjnym (np. autograf A.M. Fredry).

Przebadanie zespołu książek z bibliotek gimnazjalnych Chojnic i Chełmna pod względem proweniencyjnym pogłębiło znajomość własnych zbiorów, co jest przecież podstawowym obowiązkiem bibliotekarza sprawującego nad nimi pieczę oraz utwierdziło w przekonaniu, że nie jest to wysiłek daremny. Wymierną korzyścią jest wykazanie, że zbiory starych druków Biblioteki UMK zawierają w sobie fragmenty dawnych mniejszych księgozbiorów historycznych Pomorza, związanych z historią i kulturą Polski oraz, że przebadanie całego zasobu starych druków łącznie ze zbiorami królewieckimi pozwoli te fragmenty powiększyć. Przykładem i zachętą może być biblioteka jezuitów z Grudziądza. Przy okazji różnych prac w magazynie i bieżącej realizacji zamówień ksiażek do czytelni wynotowano już kilka książek z tą proweniencją, a następnie z pieczątką biblioteki królewieckiej ${ }^{42}$. Łącznie z tym, co wynotowano $w$ zespole chełmińskim i chojnickim daje to znaczący fragment (ponad 60 pozycji) dawnego księgozbioru jezuitów z Grudziądza.

Wyniki badań proweniencyjnych umożliwiają opracowanie nowego informatora o dawnych księgozbiorach historycznych $\mathrm{i}$ ich aktualnym miejscu przechowywania (typu „Zbiory polskie" E. Chwalewika). Jego opracowanie postuluje środowisko osób związanych z książka, skupione w Polskim Towarzystwie Bibliologicznym.

\section{Przypisy}

\footnotetext{
${ }^{1}$ Archiwum UMK. R.43. Biblioteka UMK. Zasób 1945-1947, k.30a i k.34. Rozmowa autorki z prof. L. Żytkowiczem przeprowadzona 19.06.91 r.
}

${ }^{2}$ L. Żytkiewicz sygnalizuje ich istnienie, szacunkową wartość, zawartość oraz warunki przechowywania. Lustracji tej dokonal przyjechawszy samochodem po książki do miejscowości Warcin.

${ }^{3}$ Zob. J. Nierzwicki, Biblioteka Państwowego Gimnazjum Żeńskiego w Chełmnie [W:] Biblioteki wielkopolskie i pomorskie. Poznań 1929, s. 295-298; L. Jarzębowski, Księgozbiór Biblioteki Chetmińskiej (Bibliotheca Academiae Culmensis). Jego pochodzenie i losy [W:] Zeszyty Naukowe UMK w Toruniu. Nauki Humanistyczno-Spoleczne, z. 7. Nauka o Książce, z.1, 1962, s. 11-95.

${ }^{4}$ M.in. P. Chmielecki, Gimnazjum Chelmińskie w okresie zaboru 1837-1920, Bydgoszcz 1970; Księga pamiątkowa stulecia Gimnazjum Męskiego w Chelmnie 1837-1937, Wąbrzeźno 1937; odpowiednie rozdziały w monografii "Dzieje Chelmna. Zarys monograficzny", wyd. 2 zmien. pod red. M. Biskupa, 
Warszawa 1987; B. Hoffman, Z historii Gimnazjum Państwowego w Chojnicach, Chojnice $1935 ; H$. Porożyŕski, Z dziejów Liceum Ogólnoksztalcącego im. Filomatów Chojnickich 1623-1976, cz. 1-2, Stupsk 1987; Chojnice. Dzieje miasta i powiatu, red. S. Gierowski, Wroclaw 1971; J. Szews, Język polski w szkolnictwie średnim Pomorza Gdańskiego w latach 1815-1920, Gdańsk 1975.

${ }^{5}$ Sygn. RPS.587, 2 504 s. Nie zachowal się 7-mio tomowy katalog opracowany przez Stanislawa Węclewskiego - nauczyciela najpierw w gimnazjum w Chełmnie, a od 1874 roku w Chojnicach.

${ }^{6}$ Zespót Akt Okręgu Szkolnego Pomorskiego. Sygn. 170, nr zespołu 454. Przekazanie Bibliotece Uniwersyteckiej w Poznaniu starych partii bibliotek szkolnych (do XIX w.), s. 65-78.

7 [H. Deiters], Die Handschriften und alten Drucke der hiesigen Gymnasialbibliothek [W:] Programm des Königlichen Gymnasiums in Conitz. Schuljahr 1874-75, Conitz 1875, s. 17-32.

${ }^{8} \mathrm{~S}$. Tync, Biblioteka gimnazjum w Chojnicach [W:] Biblioteki wielkopolskie i pomorskie, s. 301-305.

${ }^{9}$ Wojewódzkie Archiwum Państwowe (WAP), Toruń. Państwowe Gimnazjum Męskie, Chełmno. Sygn. $108,40 \times 25 \mathrm{~cm}, 820 \mathrm{~s}$.

10 Katalog der Lehrerbibliothek des Königlichen Gymnasiums zu Culm. Hrsg. von Professor Borowski. Culm 1901. Beigabe zum Programm N²5, $110 \mathrm{~s}$.

${ }^{11}$ Programm Königliches Gymnasium zu Culm, t. 28, Culm 1876, s. 19-23.

12 WAP, Toruń. Państwowe Gimnazjum Męskie, Chelmno, Sygn. 107. Wojciech Łożyński (18081884). Funkcję dyrektora petnił w I. 1844-1882.

${ }^{13}$ Najcenniejsze wybierano do bibliotek Berlina i Królewca. W następnej kolejności przekazywano bibliotekom szkolnym oraz bibliotece "Biskupstwa" w Pelplinie. - T. Glemma, Biblioteka Seminarium Duchownego w Pelplinie [W:] Biblioteki wielkopolskie i pomorskie, s. 290.

${ }^{14}$ M. Strutyńska, Inkunabuły proweniencji chojnickiej w zbiorach Biblioteki Uniwersyteckiej w Toruniu [W:] Studia o działalności i zbiorach Biblioteki Uniwersytetu M. Kopernika, cz. 2, Toruń 1982, s. 60. Kartoteka wszystkich wynotowanych inkunabulów znajduje się w Bibliotece UMK.

${ }^{15}$ Zob. przypis 11 . Opracowal zestawienie bibliotekarz A. Thomaszewski.

${ }^{16}$ Zreszta już w rękopiśmiennym katalogu biblioteki w uwagach spotyka się informacje o zaginięciu druków z datą i parafką stwierdzającego ten fakt, na przyklad przy pozycji: Diogenis Laertii, De vita et moribus philosophorum libri X. Lugduni 1559. Podobnie na s. 46 i 66. Przy niektórych pozycjach z XVI wieku, które były opisane według treści, jest nota: „inter dem alten Drücken". Stąd wniosek, że druki XVI wieku byly wydzielone w osobne miejsce.

17 J. Cybertowicz, H. Kowalewicz, Katalog druków polskich XVI wieku Biblioteki Glównej Uniwersytetu im. A. Mickiewicza w Poznaniu, Poznań 1963, poz. 23, 146, 147, 148, 215, $270,287$.

${ }^{18}$ Ze względu na to, że $w$ Bibliotece Uniwersyteckiej w Poznaniu nie ma kompletnych kartotek proweniencyinych, trzeba tam pojechać ze spisem starych druków chelmińskich, sprawdzić je w katalogu, a następnie zbadać $\mathrm{z}$ autopsii.

${ }^{19}$ S. Tync, op.cit., s. 303.

${ }^{20}$ Nazwiska ofiarodawców czasami wymieniano w części sprawozdawczej drukowanego programu szkolnego za dany rok szkolny.

${ }^{21}$ S. Tync, op.cit., s. 303.

${ }^{22}$ Druki XIX wieku stoja w innych magazynach, częściowo w bibliotekach zakladowych Uniwersytetu Mikołaja Kopernika: filologii klasycznej, germańskiej, historii. Część z nich, w ramach wymiany dubletów, trafila do innych instytucji.

${ }^{23}$ Bibliotekarzem biblioteki nauczycielskiej w Chojnicach był m.in. Stanislaw Węclewski. Opracował on 7-mio tomowy katalog zbiorów tej biblioteki (zob. Tync, op.cit., s. 303), który nie zachowal się. W katalogu, który jest przechowywany w Bibliotece UMK są poprawki naniesione jego ręką. Być może Węclewski był autorem spisu zamieszczonego $w$ drukowanym sprawozdaniu szkolnym za rok $1874 / 75$, gdyż był już wtedy w Chojnicach, przeniesiony tutaj z Chelmna. Zestawienie to jest jednak nie podpisane, więc przyjęto uważać ówczesnego dyrektora H. Deitersa za autora tego opracowania. 
24 Podobne nalepki mają ksiązki po Akademii Chelmińskiej z Gimnazjum Żeriskiego, ale sygnatura jest pisana inną ręką, bardzo starannym i kaligraficznym pismem, więc można je odróżnić od książek z Gimnazjum Męskiego.

25 Bernardyni przebywali w Lubawie w okresie 1502-1564 i 1580-19 .Il.1821.

26 M. Strutyŕska, Biblioteka bernardynów w Lubawie [W:] Z badań nad polskimi księgozbiorami historycznymi, t. 9, Warszawa 1986, s. 5-76.

${ }^{27}$ Reformaci przebywali w Wejherowie w l. 1649-1875. Klasztor ich wprawdzie zostal zniesiony w 1829, lecz wykonanie zarządzenia udalo się przedlużyć do 1867 roku. - Diecezja chelmińska. Zarys historyczno-statystyczny, Pelplin 1928, 5. 746. Jedna ksiązka reformatów z Wejherowa znajduje się w bibliotece Muzeum Historyczno-Etnograficznego w Chojnicach. Widziałam ją 25.IX.1989 r. [Spee Fryderyk], Cautio criminalis seu de processibus contra sagas. Posnaniae, in. off. Reguli, $1647.8^{\circ}$. E. XXIX, 111,112.

Biblioteką i dziejami klasztoru wejherowskiego zajmuje się o. Gaudenty Kustusz.

${ }^{28}$ Augustianie przebywali w Chojnicach od roku 1265 (?) - data dyskusyjna, a na pewno w latach 1356-1543 i 1623-1819. [J.] Fankidejski, Utracone kościoły i kaplice w dzisiejszej diecezji chełmirískiej, Pelplin 1880, s. 325; G. Uth, Szkic historyczno-biograficzny zakonu augustiańskiego w Polsce, Kraków 1930, s. 58.

${ }^{29}$ Dokladny opis zob. M. Strutyńska, Inkunabuty proweniencji chojnickiej..., s. 69-70.

${ }^{30}$ Bernardyni przebywali w Zamartem w I. 1747-1826. - Klasztory bernardyriskie w Polsce w jej granicach historycznych, pod red. H.E. Wyczawskiego, Kalwaria Zebrzyojowska 1985, s. 447.

31 Drugie wydanie u Förstera ukazało się w 1659, a trzecie w 1660. Czwarte z kolei wyszło w Amsterdamie w 1698. E. XVI, 307.

32 A. Kurkowa, Mało znany ekslibris Pawla Speratusa „Libri Gedanenses", t. 8, 1974, s. 159-171.

${ }^{33}$ Dokładny opis zob. M. Strutyńska, Inkunabuły proweniencji chojnickiej..., s. 65-67.

34 Jezuici przybyli do Grudziądza w 1622 roku, a kolegium otworzyli w 1637. Przebywali w Grudziądzu do kasaty zakonu.

${ }^{35}$ Sygn. Ob.6.Il.4638; Ob.7.I.124; Ob.7.I.446; Ob.7.II.6789; Ob.7.IV.131; $281102 ; 276320-276321$.

${ }^{36} \mathrm{Sz}$. Wierzchosławski, Od upadku Polski do odzyskania niepodleglości 1795-1920 [W:] Dzieje Chelmna..., s. 202.

${ }^{37}$ Z.H. Nowak, Dzieje Chermna do korica XVIII w. [W:] Dzieje Chelmna..., s. 120.

38 Sz. Wierzchosławski, op.cit., s. 250. (Ob.7.11.2219-20; Ob.7.IV.1; Ob.7.IV.32; Ob.7.IV.34; Ob.7.IV.49).

${ }^{39}$ Dane z przeszlości sa nieścisle, ponieważ opisy zawarte w źródlach nie podają ilości tomów dzieł wielotomowych, często też opisana jest tylko pierwsza pozycja z klocka. Natomiast metoda poszukiwari w oparciu o znaki zewnętr zne w dużym zbiorze książek siłą rzeczy jest również nieścisła. Nalepki mogły ulec zniszczeniu, jest też wiele ksiazzek zdefektowanych, bez karty tytułowej i pierwszych początkowych, na których na ogół zaznaczano własność. Ponadto część ksiażek otrzymała nowa oprawe już w Bibliotece UMK.

${ }^{40}$ Cytowane dane są oparte o karty główne proweniencji, a więc też nie uwzględniają wszystkich pozycji bibliograficznych w klockach, czy ilości tomów.

41 Pewna część, jak już wspomniano, znajduje się w Bibliotece Uniwersytetu w Poznaniu.

42 Sygn. Pol.7.Il.843; Pol.7.II.105; Pol.7.III.918; Pol.8.I.33-35; Pol.8.II.328; Pol.8.ll.1139; Pol.8.Il.1586.

* Dziękuję st. kust. dypl. L. Jarzębowskiemu za zawsze życzliwą pomoc przy odczytywaniu proweniencji oraz koleżankom z Oddziału za pomoc $w$ wyszukiwaniu książek w magazynie. 